\title{
Biological Control Associated With Plant Nutrition for Meloidogyne javanica and Pratylenchus brachyurus Management in Soybean
}

\author{
Ana Paula Mendes Lopes ${ }^{1}$, Bruna Orlandini Toninato ${ }^{2}$, Mayra Renata Cruz Soares ${ }^{1}$ \\ \& Cláudia Regina Dias-Arieira ${ }^{2}$ \\ ${ }^{1}$ Post-Graduate in Agronomy, State University of Maringá, Maringá, PR, Brazil \\ ${ }^{2}$ Agronomic Science Department, State University of Maringá, Umuarama, PR, Brazil \\ Correspondence: Ana Paula Mendes Lopes, Post-Graduate in Agronomy, Universidade Estadual de Maringá, \\ Avenida Colombo, n. 5790-Bloco J45, 2 Piso, 87020-900, Maringá, Paraná, Brazil. Tel: 55-44-99863-7231. \\ E-mail: anna_apml@hotmail.com
}

Received: March 10, 2019

Accepted: October 1, $2019 \quad$ Online Published: December 15, 2019

doi:10.5539/jas.v12n1p149

URL: https://doi.org/10.5539/jas.v12n1p149

\begin{abstract}
Meloidogyne javanica and Pratylenchus brachyurus stand out among the main nematodes in soybean crops. Research on integrated management are often conducted, due to the low efficiency of the main control methods when they are applied alone. Thus, the aim of the present study was to assess the potential of biological control and plant nutrition products to control these nematodes in soybean. The effect of each product alone on nematode hatching and mortality was also assessed. A greenhouse experiment was also carried out, evaluating five doses of the product for biological control based on Bacillus and Trichoderma, with and without the presence of the product for nutrition, inoculated with 2000 eggs and juveniles for the gall nematode or 1000 specimens for the nematode lesions. After 30 days of multiplication, the aerial part was removed and the soil was revolved to receive the new sowing of the soybean with the respective treatments mentioned above. After 60 days, the experiments were evaluated for nematological parameters. Both products reduced hatching and increased nematode mortality. Treatments with biological control were efficient in reducing M. javanica and $P$. brachyurus, mainly when applied at doses close to 5 and $8 \mathrm{~kg} \mathrm{ha}^{-1}$, respectively. The nutrition product negatively influences the biological control.
\end{abstract}

Keywords: alternative control, integrated management, root-knot-nematode, root-lesion nematodes

\section{Introduction}

Soybean (Glycine max (L.) Merril) cultivation in Brazil is continuously increasing, possibly due to the development of new cultivars resistant to pests and diseases, besides the expansion of new cultivated areas resulting from the developed high-technologies, from favorable weather conditions and high culture adaptability to different cultivation regions (CONAB, 2017).

Despite such improvements, some factors limit productivity. Nematodes stand out among these factors, since they cause significant growing losses. Root-knot nematodes (Meloidogyne spp.) and root-lesion nematodes (Pratylenchus brachyurus (Godfrey) Filipjev \& Sch. Stekhoven) are often associated with damages to the crop. Meloidogyne javanica (Treub) Chitwood is responsible for 10 to $40 \%$ losses, mainly in sandy and medium-sandy textured soil (Inomoto \& Silva, 2011). Cell hyperplasia and hypertrophy are characteristic symptoms of nematode-associated infections; they lead to gall formation in the root system due to root thickening in the areas affected by the sedentary females, fact that facilitates the diagnosis (Moens et al., 2009). Pratylenchus brachyurus, in its turn, causes root-lesions that get darker due to the injection of enzymes and toxins in the root cortex during nematode migration and feeding inside the root (Henning et al., 2014). Problems associated with this nematode have been related to successive cultivation of host plants after soybeans, including maize, millet and Brachiaria, as well as to the culture expansion to regions presenting sandy and low-fertility soil (Inomoto, 2011).

Managing these phytonematodes is a complex; therefore, it is necessary integrating different practices. Accordingly, the biological control has been standing out due to the introduction of antagonistic microorganisms in order to decrease damages caused to plants of economic interest (Collange et al., 2011). Rhizobacteria, mainly 
bacteria belonging to genus Bacillus, present nematicide potential, besides their potential to promote root development and plant growth (Xiong et al., 2015; Berlitz et al., 2016). Some fungi living in the soil have also been studied in order to check their potential for nematode management. Emphasis is given to Trichoderma, which has varying antagonistic-action mechanisms to control nematodes, including antibiosis, parasitism, the competition for penetration sites in the roots and resistance induction (Al-Shammari et al., 2013; Kath et al., 2017).

Other alternative consist in using products focused on nutrition, which help making minerals available for plant growth. The nutrients are responsible for increasing or reducing disease severity and for inducing host-plant resistance (Santana-Gomes et al., 2013).

Based on the aforementioned, the aim of the present study was to assess the efficiency of different doses of a product based on microorganisms (Nem-Out ${ }^{\mathrm{TM}}$ ), associated or not with a plant nutrition product (Soil-Set ${ }^{\circledR}$ ) in the $M$. javanica and P. brachyurus control in soybean, and their effect on nematode hatching and mortality.

\section{Material and Methods}

Experiment in vitro were conducted at the Laboratory of Nematology order to assess the effect of the products on nematode hatching and mortality. These experiments followed a completely randomized design with six treatments and seven repetitions.

The hatching experiment was carried out with $M$. javanica, whose eggs came from a pure population multiplied on tomato plants. Roots with egg masses were placed in $500 \mathrm{~mL}$ Erlenmeyer and added with 300 $\mathrm{mL}$ of $0.5 \%$ Sodium hypochlorite. The Erlenmeyer was closed with a rubber cap and stirred for two minutes to induce egg-detachment from the egg masses. The suspension was sieved (through 500-mesh sieve) and washed in water. Eggs were collected and calibrated to 600 eggs in $0.5 \mathrm{~mL}$ of water. The procedure was conducted in a Peters camera coupled to a light microscope.

The suspension $(0.5 \mathrm{~mL})$ containing the eggs and $9.5 \mathrm{~mL}$ of treatments were placed in Petri dishes $(8 \mathrm{~cm}$ diameter). The treatments consisted of a biological control product, Nem-Out ${ }^{\mathrm{TM}}$ (based on Bacillus subtilis (Ehrenberg) Cohn, B. licheniformis (Weigmann) Chester and Trichoderma longibrachiatum Rifai (total micro-biological counting $3.75 \times 10^{8} \mathrm{UFC} \mathrm{g}^{-1}$ ), plus protease, silanase and cellulose; the amount of these proteins was not informed by the manufacturer, Improcrop ${ }^{\circledR}$ do Brasil Ltda) at doses of 4 and $8 \mathrm{~kg} \mathrm{ha}^{-1}$, and a plant nutrition product, Soil-Set ${ }^{\circledR}$ (composed of 3.7\% sulfur $\left(33.8 \mathrm{~g} \mathrm{~L}^{-1}\right), 3.00 \%\left(36.9 \mathrm{~g} \mathrm{~L}^{-1}\right)$ copper, $1.6 \%$ iron $\left(19.7 \mathrm{~g} \mathrm{~L}^{-1}\right), 0.8 \%$ manganese $\left(9.8 \mathrm{~g} \mathrm{~L}^{-1}\right), 3.2 \%$ zinc $\left(39.4 \mathrm{~g} \mathrm{~L}^{-1}\right), 2.13 \%$ organic carbon, at density $1.23 \mathrm{~g} \mathrm{~cm}^{-3}$ and $\mathrm{pH} 2.55$, Improcrop ${ }^{\circledR}$ do Brasil Ltda) at dose of 1 and $2 \mathrm{~L} \mathrm{ha}^{-1}$. Distilled water and Furadan 350SC (Carbofuran at dose $4.5 \mathrm{~L}$ of the commercial product per hectare) were used as control.

The plates were incubated in BOD at $27^{\circ} \mathrm{C}$ and the hatched juveniles and remaining eggs were assessed eight days after incubation. The evaluations were performed in Peters camera coupled to light microscope, at 10x magnitude, and expressed in hatching percentage.

Nematodes belonging to both species were subjected to the method suggested by Coolen and D'Herde (1972) to test mortality. The suspension containing eggs and eventual juveniles was deposited in Baermann funnel (Baermann, 1917) and active nematodes were collected 24 hours later. The experiment was installed and incubated according to the procedure adopted for the hatching test. However, the evaluation was carried out 24 hours after incubation by taking into account the live and dead nematodes in the suspension. At the time of assess, in each sample was added $\mathrm{NaOH} 1 \mathrm{~N}$ at $10 \%$ of the solution volume, in order to facilitate live-nematode identification. Results were expressed in mortality percentage.

Data were subjected to analysis of variance and the means were compared by the Scott-Knott test at 5\% probability, using Sisvar statistical software (Ferreira, 2011).

Other experiment was conducted in a greenhouse, located at $23^{\circ} 47^{\prime} 28.4^{\prime \prime} \mathrm{S}$ latitude, $53^{\circ} 15^{\prime} 24.0^{\prime \prime} \mathrm{W}$ longitude, and altitude 379 meters. The study followed a completely randomized design, in a factorial $5 \times 2$, with five doses of biological control product $\left(0,2.5,5.0,7.5\right.$, and $\left.10 \mathrm{~kg} \mathrm{ha}^{-1}\right)$, with and without the plant nutrition product, and six repetitions for each treatment.

The experiment with M. javanica was conducted from December 2015 to March 2016 (Mj-2016), under mean minimum and maximum temperatures 16.9 and $29.3{ }^{\circ} \mathrm{C}$, respectively, and was repeated between November 2016 and February $2017(\mathrm{Mj}-2017)$, when temperatures were 15.5 and $26.1^{\circ} \mathrm{C}$, respectively. The experiment with $P$. brachyurus was carried out simultaneously to the experiment with M. javanica in the 2016 year. 
Nematodes were multiplied in the experimental units, aiming at simulating the field condition under which nematodes are living in the soil and in root remnants. In order to do so, soybean cv. Pintado seedlings were produced on trays filled with BioPlant ${ }^{\circledR}$ commercial substrate; 15 days after germination they were transplanted to pots filled with $3.5 \mathrm{~kg}$ of a mixture containing soil and sand (2:1), previously autoclaved at $120{ }^{\circ} \mathrm{C}$ for 2 hours. Seedlings were inoculated with a population of approximately 2000 eggs and eventual second-stage juveniles (J2) of M. javanica, or with 1000 P. brachyurus specimens, three days after the transplant. The inocula were distributed in $3 \mathrm{~mL}$ of water and deposited in two holes $(2 \mathrm{~cm}$ deep) opened in the soil around the plant, which was closed after the inoculation. The M. javanica and P. brachyurus inocula were obtained from pure population kept on tomato plants cv. Santa Clara and on maize cv. AL Bandeirante, respectively. They were extracted according to the methodology suggested by Hussey and Barker, adapted by Boneti and Ferraz (1981), and Coolen and D'Herde (1972), respectively.

After 30 days, aerial part was eliminated, and the soil was slightly revolved for soybean sowing. The biological control product was applied on the sowing groove, at the doses mentioned, with or without the plant nutrition product, also applied on the sowing groove, at dose $1 \mathrm{~L}$ of commercial product (Soil-Set ${ }^{\circledR}$ ) per hectare, in $1 \mathrm{~L}$ of water. Plant-nutrition product application was repeated on the surface thirty days after the first application in the units treated with Soil-Set ${ }^{\mathbb{R}}$.

The plants were kept in greenhouse for 60 days and were daily irrigated. They were collected after this period and the root system was separated from the aerial part. The root systems were carefully washed and placed on absorbent paper to eliminate water excess; subsequently, the root fresh weight was determined. They were subjected to the aforementioned extraction methods, the total number of nematodes per root system was assessed under a Peters camera coupled to a light microscope. The recorded value was divided by the root weight to find the number of nematodes per root gram. The height, and the dry and fresh weights, of the aerial part was determined. The dry weight was found through drying in forced air circulation oven at $65{ }^{\circ} \mathrm{C}$ until reaching the constant weight.

Data were subjected to analysis of variance at $5 \%$ probability; in case of significant results, the doses were evaluated in the nutrition factor. These doses were assessed through regression analysis. If the nutrition factor was significant, the means were compared through the Bonferroni $\mathrm{T}$ test in the Sisvar statistical software (Ferreira, 2011).

\section{Results}

Except for Nem-Out $4 \mathrm{~kg} \mathrm{ha}^{-1}$, all other treatments reduced the hatching of $M$. javanica juveniles; and all treatments, including Nem-Out $4 \mathrm{~kg} \mathrm{ha}^{-1}$, led to nematode mortality and did not differ from Furadan 350SC (Table 1). With regard to P. brachyurus, although the treatments have caused nematode mortality, in comparison to the controls, the percentages were lower than that of Furadan 350SC.

Table 1. Hatching and mortality percentage of Meloidogyne javanica (Mj), and mortality percentage of Pratylenchus brachyurus $(\mathrm{Pb})$ subjected to different treatments assessed 8 days after inoculation (DAI) in the hatching test, and 24 hours for mortality

\begin{tabular}{|c|c|c|c|}
\hline Treatments & Hatching of $\mathrm{Mj}(\%)$ & Mortality of $\mathrm{Mj}(\%)$ & Mortality of $\mathrm{Pb}(\%)$ \\
\hline Control & $42 \mathrm{a}$ & $0 \mathrm{~b}$ & $0 \mathrm{c}$ \\
\hline Furadan $350 \mathrm{SC}$ & $27 \mathrm{~b}$ & $100 \mathrm{a}$ & $95 \mathrm{a}$ \\
\hline Nem-Out ${ }^{\mathrm{TM}} 4 \mathrm{~kg} \mathrm{ha}^{-1}$ & $41 \mathrm{a}$ & $100 \mathrm{a}$ & $74 \mathrm{a}$ \\
\hline Nem-Out ${ }^{\mathrm{TM}} 8 \mathrm{~kg} \mathrm{ha}^{-1}$ & $16 \mathrm{c}$ & $100 \mathrm{a}$ & $33 \mathrm{~b}$ \\
\hline Soil-Set $^{\circledR} 1 \mathrm{~L} \mathrm{ha}^{-1}$ & $26 \mathrm{~b}$ & $100 \mathrm{a}$ & $35 \mathrm{~b}$ \\
\hline Soil-Set $^{\mathbb{R}} 2 \mathrm{~L} \mathrm{ha}^{-1}$ & $12 \mathrm{c}$ & $100 \mathrm{a}$ & $19 \mathrm{~b}$ \\
\hline $\mathrm{CV}(\%)$ & 22.31 & 5.42 & 16.47 \\
\hline
\end{tabular}

Note. Means followed by the same letter in the column did not differ from each other in the Scott-Knott test at 5\% probability. $\mathrm{CV}=$ coefficient of variation.

There was no interaction between the biological control and nutrition factors in experiments conducted in 2016 with M. javanica (Mj-2016). Total number of eggs $+\mathrm{J} 2$ was influenced by the treatment with biological control, which recorded maximum reduction in the dose $4.06 \mathrm{~kg} \mathrm{ha}^{-1}$ of the product (Figure 1A). 


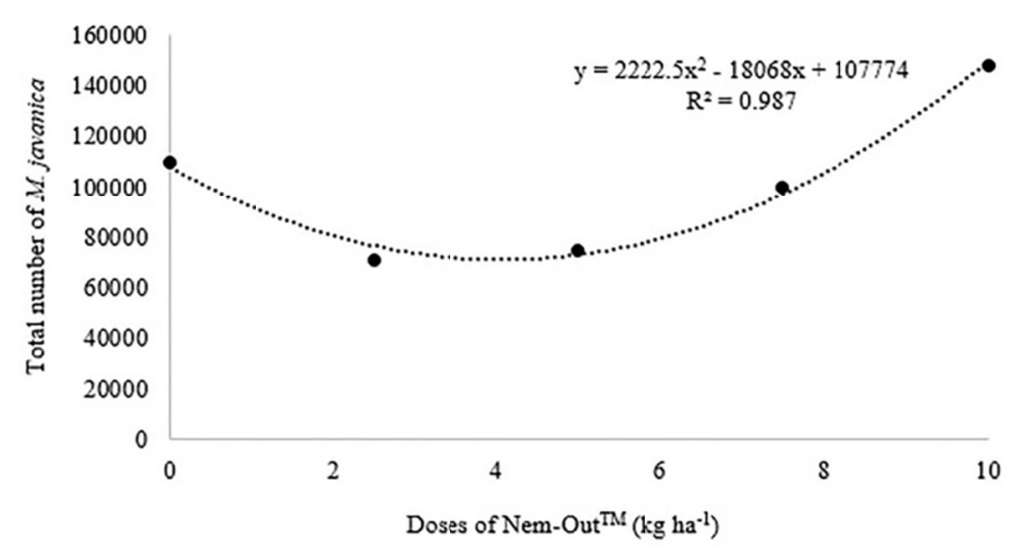

Figure 1A. Total number of Meloidogyne javanica in soybean roots subjected to treatment with increasing doses of the biological control product $\left(\mathrm{Nem}-\mathrm{Out}{ }^{\mathrm{TM}}\right) 60$ days after treatments. $\mathrm{Mj}-2016$

On the other hand, the nutrition product negatively affected the biological control; general means were equal to 64825 and 147647 eggs $+\mathrm{J} 2$ per root system in the treatments with and without plant nutrition, respectively. There was interaction between the factors in $\mathrm{Mj}$-2017; results corroborate those from 2016, since the nutrition product led to increase in the total number of M. javanica in the root system (Figure 1B), whereas its absence reduced nematode multiplication. In this case, the application of $5.31 \mathrm{~kg} \mathrm{ha}^{-1}$ of biological control product was the best control, since it reduced by approximately $55 \%$ the total of eggs $+\mathrm{J} 2$ per root system.

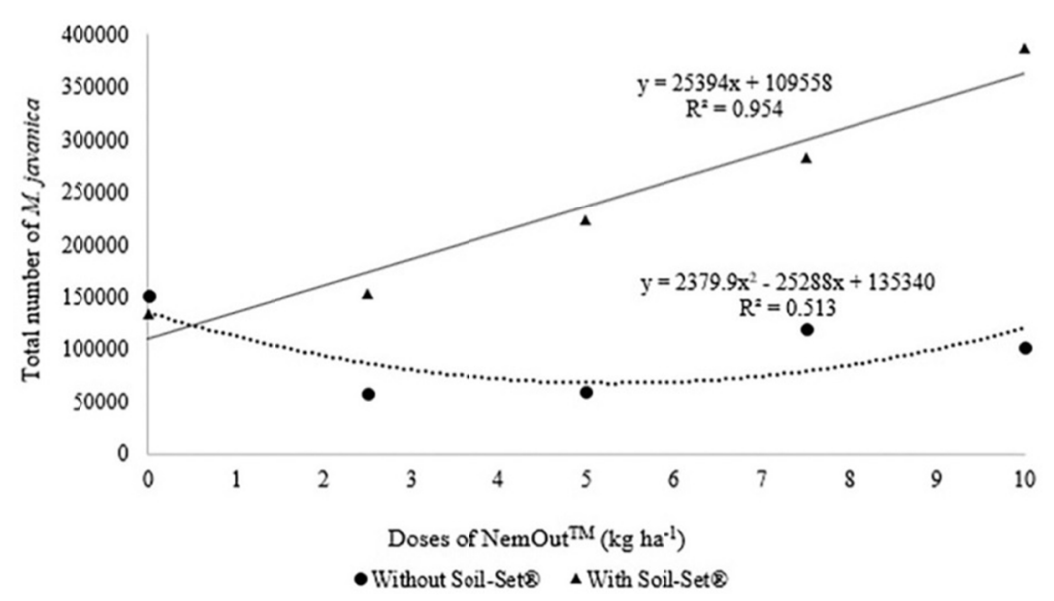

Figure 1B. Total number of Meloidogyne javanica in soybean roots, submitted to treatment with increasing doses of the biological control product $\left(\mathrm{Nem}-\mathrm{Out}^{\mathrm{TM}}\right.$ ), without or with nutrition product (Soil-Set ${ }^{\circledR}$ ), 60 days after treatments. $\mathrm{Mj}-2017$

Data about the total of eggs $+\mathrm{J} 2$ parameter directly reflected the number of eggs $+\mathrm{J} 2 \mathrm{~g}^{-1}$ of root. Therefore, there was interaction between factors in both experiments; once more, the nutrition factor negatively influenced the biological control. The use of biological control without the nutrition factor in Mj-2016 recorded maximum reduction when $4.69 \mathrm{~kg} \mathrm{ha}^{-1}$ of the product was applied; the minimum number of eggs $+\mathrm{J} 2$ was equal to 2936 . On the other hand, the same number was 21362 (number resulting from the derivative and from the integral of the equations) at the best dose $\left(2.84 \mathrm{~kg} \mathrm{ha}^{-1}\right)$ with the nutrition factor (Figure $\left.2 \mathrm{~A}\right)$. 


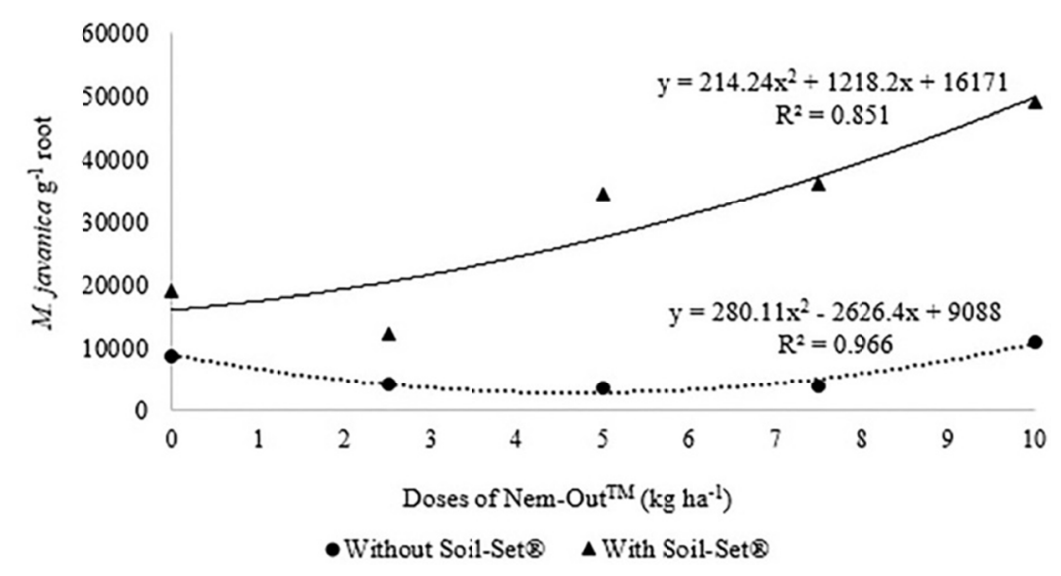

Figure 2A. Total number of Meloidogyne javanica in soybean roots, submitted to treatment with increasing doses of the biological control product $\left(\mathrm{Nem}-\mathrm{Out}^{\mathrm{TM}}\right.$ ), without or with nutrition product $\left(\mathrm{Soil}_{-} \mathrm{Set}^{\mathbb{B}}\right.$ ), 60 days after treatments. $\mathrm{Mj}-2016$

Yet in this experiment, the values of eggs $+\mathrm{J}_{2} \mathrm{~g}^{-1}$ of root recorded for the controls with and without the nutrition factor were 8892 and 19094, respectively. The biological control applied without nutrition in 2017 recorded maximum $M$. javanica reduction (1600 eggs $+\mathrm{J} 2)$ at dose $5.62 \mathrm{~kg} \mathrm{ha}^{-1}$, whereas the increase in the number of eggs $+\mathrm{J} 2$ was directly proportional to the dose increase within the nutrition factor (Figure 2B).

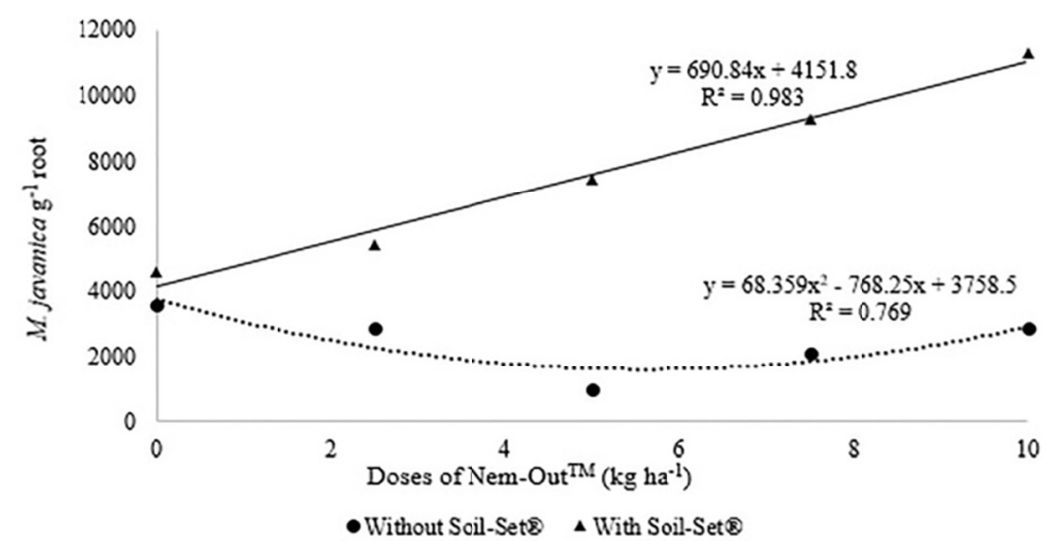

Figure 2B. Meloidogyne javanica $\mathrm{g}^{-1}$ of soybean roots, submitted to treatment with increasing doses of the biological control product $\left(\mathrm{Nem}-\mathrm{Out}^{\mathrm{TM}}\right)$, without or with nutrition product $\left(\right.$ Soil-Set $\left.^{\mathbb{B}}\right)$, 60 days after treatments. $\mathrm{Mj}-2017$

The negative effect of the nutrition product was once more observed in the experiment with P. brachyurus. In this case, the analysis was only significant for the number of nematodes $\mathrm{g}^{-1}$ of root, since there was interaction between factors and best nematode control was recorded for the use of biological control alone at dose $8.24 \mathrm{~kg}$ $\mathrm{ha}^{-1}$ of the product (Figure 3). 


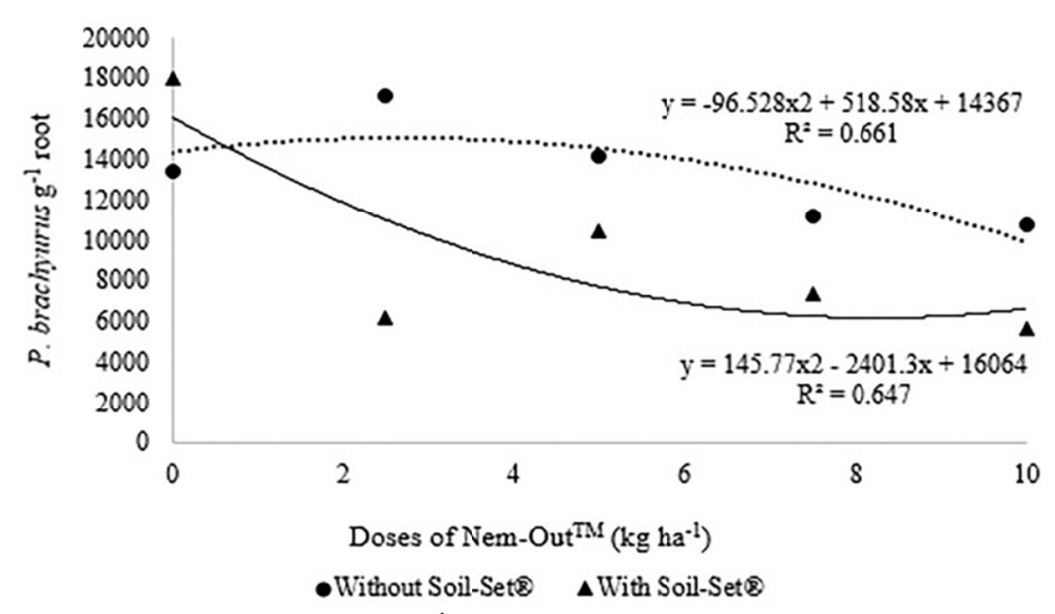

Figure 3. Number of Pratylenchus brachyurus $\mathrm{g}^{-1}$ soybean root, submitted to treatment with increasing doses of the biological control product 60 days after treatments. Year 2016

With regard to the vegetative parameters of the experiment with M. javanica conducted in 2016 (Mj-2016), the different doses of the biological control product, as well as the interaction between biological control and nutrition, did not influence plant height, although the nutrition factor was significant, since the means were 27.61 and $35.12 \mathrm{~cm}$ in treatments with and without the nutrition factor, respectively. Similar result was observed in Mj-2017, when plant height was negatively influenced by nutrition.

Fresh and dry weight of the aerial part in the experiment with M. javanica in 2016 recorded 2.95 and $6.43 \mathrm{~g}$, and 0.98 and $1.97 \mathrm{~g}$ in treatments with and without nutrition, respectively. The root was also influenced by nutrition, since it recorded the respective means 6.73 and $12.48 \mathrm{~g}$. In 2017, the fresh and dry weight of the aerial part recorded 30.49 and $45.98 \mathrm{~g}$, and 9.07 and $12.19 \mathrm{~g}$ in treatments with and without this product, respectively. Yet in Mj-2016, the root weight was not affected by the treatments or by the interaction between them.

The experiment with P. brachyurus showed that the factors, as well as the interaction between them, did not influence plant height and the dry weight of the aerial part. The nutrition factor was significant for the dry weight of the aerial part, since it negatively influenced it; means were 11.3 and $13.4 \mathrm{~g}$ plants treated, or not, with the product. Similar results were recorded for the root weight, whose respective means were 19.6 and $22.9 \mathrm{~g}$.

\section{Discussion}

The two assessed products promote reduced $M$. javanica juvenile hatching and nematode mortality (Table 1). The action of Nem-Out ${ }^{\mathrm{TM}}$ could have happen through antibiosis, since the microorganisms can produce nematicide substances capable of inhibit hatching and increase nematode mortality (Szábo et al., 2012). Soil-Set ${ }^{\circledR}$, in its turn, is composed of nutrients (sulfur, copper, iron, manganese and zinc) that can have straight action on nematodes. Iron was efficient in reducing the $M$. incognita population when nanoparticles of it were used in okra, either in tests in vitro or in vivo (Sharma et al., 2017). Song et al. (2014) assessed the cooper effect on Caenorhabditis elegans Maupas, in electronic microscope and found that the nutrient causes changes in nematode cuticle, as well as on some nematode biological functions. However, it was observed that zinc did not have effect on M. incognita juvenile hatching (Couto et al., 2016).

The present study showed that, regardless of the dose, biological control application reduced the multiplication of both nematodes (Figures 1 to 5). The efficiency of this product $\left(\mathrm{Nem}-\mathrm{Out}^{\mathrm{TM}}\right.$ ) was previously proved by the $M$. javanica and P. brachyurus population reduction in soybean (Miamoto et al., 2017) and Meloidogyne incognita (Kofoid \& White) Chitwood in tomato (Silva et al., 2017). Likely, the product effect regards the microorganisms composing it; thus, $B$. subtilis has been one of the most studied bacteria to nematodes biological control. Its efficiency was previously observed in the reduction of nematodes of soybean-cyst nematodes (Heterodera glycines Ichinohe) (Araújo et al., 2002). It was also efficient in reducing P. brachyurus and Rotylenchulus reniformis Linford \& Oliveira in cotton plants, whose control was similar to the use of chemical nematicide (Higaki \& Araújo, 2012), besides the results recorded for Meloidogyne spp. management in tomato plants and in soybean with the same bacterium (Araújo et al., 2012).

Genus Bacillus has different mechanisms capable of help controlling nematodes, including the production of toxins, enzymes and other metabolic products that can change nematode orientation towards the plant roots 
(Araújo et al., 2002). Such bacteria are also known by their efficiency in degrading root exudates responsible for stimulating recently-hatched juveniles migration; thus impairing root location by the nematodes (Araújo et al., 2002). Moreover, there are reports about bacteria belonging to genus Bacillus that are capable of inducing plant resistance to many pathogens, including nematodes (Sikora et al., 2007; Adam et al., 2014; Zhang et al., 2016).

The presence of fungus Trichoderma likely contributed to the results, since many species and isolates of this fungus are efficient to nematode biological control in many pathosystems, including T. longibrachiatum. It was the biocontrol agent against M. javanica and M. incognita in tomato plants (Al-Shammari et al., 2013; Silva et al., 2017), and Heterodera avenae Wollenweber in wheat (Zhang et al., 2014, 2017). Although the action-mechanism used by genus Trichoderma acting in nematode management is not completely elucidated, but some authors report the direct parasitism of eggs and juveniles (Suárez et al., 2004; Al-Shammari et al., 2013). Besides this, these fungi can produce enzymes, including chitinase, protease and other lytic enzymes that, when secreted, can penetrate the J2-cuticle and egg gelatinous-matrix, thus severely changing their physical integrity (Al-Shammari et al., 2013; Zhang et al., 2014, 2017), which may also explain the reduction in hatching and increase in mortality observed in this study (Table 1).

Trichoderma spp. has also been cited as plant systemic resistance inductor (Contreras-Cornejo et al., 2009; Al-Shammari et al., 2013; Zhang et al., 2014; Kath et al., 2017); the study with $T$. longibrachiatum-wheat- $H$. avenae showed significant enzymatic activity increase (peroxidase, polyphenol oxidase and phenylalanine ammonia-lyase). These enzymes are related to nematode resistance induction, and this mechanism is the key to suppress pathogens development (Zhang et al., 2014).

With regard to the current study, the use of Soil-Set ${ }^{\mathbb{B}}$ as vegetal nutrition product negatively influenced the $M$. javanica and P. brachyurus control (Figures 2, 3, and 4). Likely, such result derives from the presence of substances such as copper and sulfur, which may have had deleterious effect on the antagonistic microorganisms composing the biological control product, since there are reports about copper capacity to reduce the lifetime of bacterium Bacillus thuringiensis Berliner in greenhouse and in the field (Haddad et al., 2011). However, this product has the potential to nurture the plant and to manage nematodes, besides its possible potential to induce resistance when it is applied on the aerial parts (Miamoto et al., 2017), without any close contact with the microorganisms.

Treatments used in the present study did not promote vegetative enhancement, and it corroborated results found in other studies that used the same product (Nem-Out ${ }^{\mathrm{TM}}$ ) to control M. incognita in tomato plants (Silva et al., 2017), and M. javanica and P. brachyurus in soybean (Miamoto et al., 2017). However, research point out the potential of both genera to promote plant growth (Baños et al., 2010; Souza \& Debastiani, 2015), since their permanence time, as well as the edaphic-climatic factors, can be responsible for the difference in the results.

In conclusion, the product based on Bacillus and Trichoderma is presented as effective alternative in the management of $M$. javanica and $P$. brachyurus in soybean, mainly when applied at doses close to $5 \mathrm{~kg} \mathrm{ha}^{-1}$ and 8 $\mathrm{kg} \mathrm{ha}^{-1}$, respectively. The plant nutrition product (Soil-Set ${ }^{\mathbb{B}}$ ) had an antagonistic effect on the biological control, not being recommended its association with the biological products.

\section{References}

Adam, M., Heuer, H., \& Hallmann, J. (2014). Bacterial antagonists of fungal pathogens also control root-knot nematodes by induced systemic resistance of tomato plants. Plos One, 9(2), 1-8. https://doi.org/10.1371/ journal.pone.0090402

Al-Shammari, T. A., Bahkali, A. H., Elgorban, A. M., El-Kahky, M. T., \& Al-Sum, B. A. (2013). The use of Trichoderma longibrachiatum and Mortierella alpina against root-knot nematode, Meloidogyne javanica on tomato. Journal of Pure and Applied Microbiology, 7, 199-207.

Antoniolli, Z. I., Santos, L. C., Lupatini, M., Leal, L. T., Schirmer, G. K., \& Redin, M. (2010). Efeito do cobre na população de bactérias e fungos do solo, na associação micorrízica e no cultivo de mudas de Eucalyptus grandis W. Hill ex Maiden, Pinus elliotti Englem e Peltophorum dubium (Sprengel) Taubert. Ciência Florestal, 20(3), 419-428. https://doi.org/10.5902/198050982057

Araújo, F. F., \& Marchesi, G. V. P. (2009). Uso de Bacillus subtilis no controle da meloidoginose e na promoção do crescimento do tomateiro. Ciência Rural, 39(5), 1558-1561. https://doi.org/10.1590/S0103-8478200900 0500039

Araújo, F. F., Bragante, R. J., \& Bragante, C. E. (2012). Controle genético, químico e biológico de meloidoginose na cultura da soja. Pesquisa Agropecuária Tropical, 42(2), 220-224. https://doi.org/10.1590/ S1983-40632012000200013 
Araújo, F. F., Silva, J. F. V., \& Araújo, A. S. F. (2002). Influência de Bacillus subtilis na eclosão, orientação e infecção de Heterodera glycines em soja. Ciência Rural, 32(2), 197-203. https://doi.org/10.1590/S010384782002000200003

Baermann, G. (1917). Eine einfache Methode zur Auffi ndung von Ankylostomum (Nematoden) larven in Erdproben. Geneeskundig Tijdschrift voor Nederlandsch, 57, 131-137.

Baños, Y. S., Concepcióm, A. B., Lazo, R. C., González, I. A., \& Morejón, L. P. (2010). Efecto de enmiendas orgánicas y Trichoderma spp. en el manejo de Meloidogyne spp. Revista Brasileira de Agroecologia, 5(2), 224-233.

Berlitz, D. L., Rabinovitch, L., Machado, V., Santin, R. C., Guimarães, A. M., Matsumura, A. T. S., \& Cassal, M., Fiuza, L. M. (2016). Evaluation of biocontrol of the Meloidogyne javanica with Bacillus subtilis and Purpureocillium lilacinus in greenhouse with lettuce. International Journal of Research in Engineering, 6(7), 38-45.

Boneti, J. I. S., \& Ferraz, S. (1981). Modificação do método de Hussey e Barker para extração de ovos de Meloidogyne exigua de raízes de cafeeiro. Fitopatologia Brasileira, 6(3), 553-553.

Collange, B., Navarrete, M., Peyre, G., Mateille, T., \& Tchamitchian, M. (2011). Root-knot nematode (Meloidogyne) management in vegetable crop production: The challenge of an agronomic system analysis. Crop Protection, 30(10), 1251-1262. https://doi.org/10.1016/j.cropro.2011.04.016

CONAB. (2017). Acompanhamento da safra brasileira de grãos, V. 4-Safra 2016/2017-Sétimo levantamento (p. 1-162). Brasília, Brazil. Retrieved July 14, 2017, from http://www.conab.gov.br/OlalaCMS/uploads/ arquivos/17_04_12_08_25_29_boletim_graos_abril_2017.pdf

Contreras-Cornejo, H. A., Macías-Rodríguez, L., Cortés-Penagos, C., \& López-Bucio, J. (2009). Trichoderma virens, a plant beneficial fungus, enhances biomass production and promotes lateral root growth through an auxin dependent mechanism in Arabidopsis. Plant Physiology, 149(3), 1579-1592. https://doi.org/10.1104/ pp.108.130369

Coolen, W. A., \& D'Herde, C. J. (1972). A method for the quantitative extration of nematodes from plant tissue. State Agriculture Research Center, Ghent.

Couto, E. A. A., Dias-Arieira, C. R., Kath, J., Homiak, J. A., \& Puerari, H. H. (2016). Boron and zinc inhibit embryonic development, hatching and reproduction of Meloidogyne incognita. Acta Agriculturae Scandinavica, Section B, Soil and Plant Science, 66(4), 346-352. https://doi.org/10.1080/09064710. 2015.1118154

Ferreira, D. F. (2011). Sisvar: A computer statistical analysis system. Ciência e Agrotecnologia, 35(6), 1039-1042. https://doi.org/10.1590/S1413-70542011000600001

Haddad, F., Maffia, L. A., Mizubuti, E. S. G., \& Romeiro, R. S. (2011). Sobrevivência de Bacillus thurigiensis, antagonista a Hemileia vastatrix, no filoplano de cafeeiros. Congresso Brasileiro de Defensivos Agrícolas Naturais, 5, 2011, Jaguariúna. Jaguariúna: Embrapa Meio ambiente.

Henning, A. A., Almeida, A. M. R., Godoy, C. V. G., Seixas, C. D. S., Yorinori, J. T., Costamilan, L. M., ... Dias, W. P. (2014). Manual de identificação de doenças de soja (5th ed., Embrapa Soja 76). Londrina: Embrapa.

Higaki, W. A., \& Araújo, F. F. (2012). Baccilus subtilis e abamectina no controle de nematoides e alterações fisiologicas em algodoeiro cultivado em solos naturalmente infestados. Nematropica, 42(2), 295-303.

Howell, C. R., Hanson, L. E., Stipanovic, R. D., \& Puckhaber, R. D. (2000). Induction of terpenoid synthesis in cotton roots and control of Rhizoctonia solani by seed treatment with Trichoderma virens. Phytopathology, 90(3), 248-252. https://doi.org/10.1094/PHYTO.2000.90.3.248

Inomoto, M. M. (2011). Avaliação da resistência de 12 híbridos de milho a Pratylenchus brachyurus. Tropical Plant Pathology, 36(5), 308-312. https://doi.org/10.1590/S1982-56762011000500006

Inomoto, M. M., \& Silva, R. A. (2011). Importância dos nematóides da soja e influência da sucessão de cultura. Boletim de Pesquisa da Soja, 15, 392-399.

Juhász, A. C. P., Pádua, G. P., Wruck, D. S. M., Favoreto, L., \& Ribeiro, N. R. (2013). Desafios fitossanitários para a produção de soja. Informe Agropecuário, 34(276), 66-75. 
Kath, J., Dias-Arieira, C. R., Ferreira, J. C. A., Homiak, J. A., Silva, C. R., \& Cardoso, C. R. (2017). Control of Pratylenchus brachyurus in soybean with Trichoderma spp. and resistance inducers. Journal of Phytopathology, 165(11-12), 1-9. https://doi.org/10.1111/jph.12619

Manju, P., \& Subramanian, S. (2016). Induction of systemic resistance in Gerbera jamesonii by Bacillus spp. against root knot nematode Meloidogyne incognita. Indian Journals, 5, 3286-3289.

Miamoto, A., Silva, M. T. R., Dias-Arieira, C. R., \& Puerari, H. H. (2017). Alternative products for Pratylenchus brachyurus and Meloidogyne javanica management in soya bean plants. Journal of Phytopathology, 165(10), 1-6. https://doi.org/10.1111/jph.12602

Moens, M., Perry, R. N., \& Satrr, J. L. (2009). Meloidogyne species-adiverse group of novel and important plant parasites. Root-knot nematodes. Wallingford: CABI International.

Prato, S. S. S., Rodriguez, M., Luis, M. L. S., Penã, A. S., \& Santana, I. A. R. (2016). Efectividad de Trichoderma harzianum sobre la población de nemátodos fitopatógenos en café (Coffea arabica L.) En condiciones de vivero en el municipio Junín, estado Táchira. Universidad \& Ciencia, 5(2), 01-12.

Santana-Gomes, S. M., Dias-Arieira, C. R., Roldi, M., Dadazio, T. S., Marini, P. M., \& Barizao, D. A O. (2013). Mineral nutrition in the control of nematodes. African Journal of Agricultural Research, 8(21), 2413-2420. https://doi.org/10.5897/AJARx12.008

Sharma, H., Dhirta, B., \& Shirkot, P. (2017). Evaluation of biogenic iron nano formulations to control Meloidogyne incognita in okra. International Journal of Chemical Studies, 5, 1278-1284. https://doi.org/ 10.2478/v10045-009-0053-x

Sikora, R. A., Schäfer, K., \& Dababat, A. A. (2007). Modes of action associated with microbially induce in planta suppression of plant-parasitic nematodes. Australasian Plant Pathology, 36(2), 124-134. https://doi.org/10.1071/AP07008

Silva, J. O., Santana, M. V., Freire, L. L., \& Rocha, M. R. (2017). Biocontrol agents in the management of Meloidogyne incognita in tomato. Ciência Rural, 47(10), 1-7. https://doi.org/10.1590/0103-8478cr20 161053

Song, S., Guo, Y., Zhang, X., Zhang, X., Zhang, J., \& Ma, E. (2014). Changes to cuticle surface ultrastructure and some biological functions in the nematode Caenorhabditis elegans exposed to excessive copper. Archives Environmental Contamination and Toxicology, 66(3), 390-399. https://doi.org/10.1007/s00244013-9991-4

Souza, B. L. P., \& Debastian, N. R. (2015). Biological products can reduce the nematode galls on rainfed rice cultivation? Journal of Bioenergy and Food Science, 2(1), 32-38.

Suárez, M. B., Rey, M., Castillo, P., Monte, E., \& Llobell, A. (2004). Isolation and characterization of PRA1, a trypsinlike protease from the biocontrol agent Trichoderma harzianum CECT 2413 displaying nematicidal activity. Applied. Microbiology Biotechnology, 65(1), 46-55. https://doi.org/10.1007/s00253-004-1610x

Szabó, M., Csepregi, K., Gálber, M., Virányt, F., \& Fekete, C. (2012). Control plant-parasitic nematodes with Trichoderma species and nematode-trapping fungi: The role of chi18-5 and chi18-12 genes in nematode egg-parasitism. Biological Control, 63(2), 121-128. https://doi.org/10.1016/j.biocontrol.2012.06.013

Xiong, J., Zhou, Q., Luo, H., Xia, L., Li, L., Sun, M., \& Yu, Z. (2015). Systemic nematicidal activity and biocontrol efficacy of Bacillus firmus against the root-knot nematode Meloidogyne incognita. World Journal of Microbioly Biotechnology, 31(4), 661-667. https://doi.org/10.1007/s11274-015-1820-7

Zhang, F., Peng, D., Cheng, C., Zhou, W., Ju, S., Wan, D., ... Sun, M. (2016). Bacillus thuringiensis crystal protein Cry6Aa triggers Caenorhabditis elegans necrosis pathway mediated by aspartic protease (ASP-1). PLoS Pathogens, 12, e1005389. https://doi.org/10.1371/journal.ppat.1005389

Zhang, S., Gan, Y., \& Xu, B. (2014). Efficacy of Trichoderma longibrachiatum in the control of Heterodera avenae. Biocontrol, 59(3), 319-33. https://doi.org/10.1007/s10526-014-9566-y

Zhang, S., Gan, Y., Ji, W., Xu, B., Hou, B., \& Liu, J. (2017). Mechanisms and characterization of Trichoderma longibrachiatum T6 in suppressing nematodes (Heterodera avenae) in wheat. Frontiers Plant Microbe Interactions, 645, 1-16. https://doi.org/10.3389/fpls.2017.01491 


\section{Copyrights}

Copyright for this article is retained by the author(s), with first publication rights granted to the journal.

This is an open-access article distributed under the terms and conditions of the Creative Commons Attribution license (http://creativecommons.org/licenses/by/4.0/). 